\title{
Identification of informative markers of agronomic traits in different ecotypes of sand plantain (Plantago psyllium)
}

\author{
Mehdi Rahimi ${ }^{1 \star}$, \\ Hamid Hatami Maleki², \\ Mojtaba Mortezavi ${ }^{1}$ \\ ${ }^{1}$ Department of Biotechnology, \\ Institute of Science and High Technology \\ and Environmental Sciences, \\ Graduate University of \\ Advanced Technology, Kerman, Iran \\ ${ }^{2}$ Department of Agronomy \\ and Plant Breeding, \\ Faculty of Agriculture, \\ University of Maragheh, \\ Maragheh, Iran
}

To investigate the relationships between agronomic traits and molecular markers in sand plantain (Plantago psyllium), a set of 17 ecotypes collected in Iran were evaluated. Twelve ISSR primers were tested through multiple regression analysis to identify the marker-trait association between ISSR data and agronomic traits. Finally, the 12 primers amplified 129 fragments (loci) among ecotypes: 91 fragments (70.54\%) of the 129 fragments showed polymorphism with an average of $7.58 \%$ per primer and the rate of this polymorphism ranged from at least $57.14 \%$ for UBC824 primer up to $54.62 \%$ for UBC813 primer. Polymorphic information content ranged from 0.27 (UBC814) to 0.41 (UBC813), with an average of 0.36 . Stepwise regression analysis between the molecular data as independent variables and the studied traits as dependent variables was performed to identify informative markers associated with the agronomic traits. Seventy ISSR fragments were found associated with eight morphological traits. Some of ISSR markers were associated with more than one trait in multiple regression analysis that may be due to the pleiotropic effect of the linked quantitative trait locus on different traits or is linkage of different genes. However, for a better understanding of these relationships, preparation of a segregating population and linkage mapping are necessary. Also, these result could be useful in marker-assisted breeding programmes when no other genetic information is available.

Keywords: ISSR markers, marker-trait association, multiple regression, polymorphism

\section{INTRODUCTION}

Plantago (Plantaginaceae family) is a large genus of herbs or sub-shrubs distributed mostly in the temperate region and a few in the tropics. It comprises

"Corresponding author. Email: mehdi83ra@yahoo.com about 200 species, of which only two species, P. ovate and P. psyllium, are economically important (Rahn, 1996). Plantago seed, known commercially as black, French, or Spanish psyllium, is obtained from P. Psyllium L., also known as sand plantain, French, or dark psyllium (Atal, Kapur, 1982). Plantago psyllium is an annual fluff plant the height of which varies from 15 to $40 \mathrm{~cm}$. The flowers are 
tiny and white to greenish, placed on a flowery spike. The fruit is an oval-shaped capsule containing two elongated elliptical seeds, of bright shiny brown to reddish colour (Ghahreman, 1975). This plant is well adapted to different climatic conditions and can be planted in arid and semi-arid regions. During most of the growing season, Plantago psyllium needs a cool and dry climate (Davazdah Emami, Majnoon Hosseini, 2008). The seeds of Plantago psyllium contain mucilage, protein, oil, starch, tannin (Kang et al., 2007), as well as glycoside called aucubin and different bases, some sugar, sterols, and protein (Deokar et al., 2016). Mucilage is the dominant component in Plantago psyllium; it also contains aucubin and pyridine alkaloids (including plantagin) (Rosatti, 1984).

A major revolution in plant breeding occurred with the development of markers based on DNA polymorphisms. These types of markers have been superseded by DNAbased methods that generate "fingerprints", which are distinctive patterns of DNA fragments typically subjected to high-resolution gel electrophoresis and detected by staining or labeling (Schulman, 2007). Inter-simple sequence repeat (ISSR) markers are alternatives to the RAPD technique: they allow higher annealing temperatures to be used so it has better reproducibility compared to some other markers. Repeat-anchored or non-anchored primers in the polymerase chain reaction (PCR) are used to amplify DNA sequences between two inverted SSR (Zietkiewicz et al., 1994)1994. Finding an association between molecular markers and morphological traits provides an excellent tool for indirect selection of a trait of interest in the population. This has important applications for the study of relations between molecular markers and agronomic traits, some of which include: the detection and analysis of potential in specific genotypes, collections of germplasm, identification of desirable alleles, and validation of candidate markers linked to quantitative traits (Gebhardt et al., 2004). Although the mapping of quantitative trait loci (QTLs) is well suited for detection of genes associated with the traits, it is labour intensive, while segregating population preparation is both time consuming and costly (Rakshit et al., 2010). In order to overcome these limitations, multiple regression analysis offers an appropriate method to identify markers associated with the trait. Multiple regression analysis is a statistical process for estimating the relationships among molecular markers as independent variables and morphological traits as dependent variables. It is the way to determine the coefficient of determination $\mathrm{R}^{2}$; it gives the proportion of the variance (fluctuation) of dependent variable that is predictable from the independent variable (Gomez, Gomez, 1984). Multiple regression analysis does not require a genetic map to be applied, and the method is quick, multiple unlinked QTLs are accounted, problems with multiple testing are reduced, and computer software is readily available. However, a major disadvantage with the multiple regression approach to mapping QTLs is the requirement that the independent variable, marker genotype, be available for all records included in the analysis (Henshall, Goddard, 1999).

According to the study of Khadivi-Khub (2014) by multiple regression analysis, 33 SSR alleles and 135 RAPD fragments were found associated with 14 of affecting fruit traits. Some of SSR and RAPD markers were associated with more than one fruit trait in multiple regression analysis. Marsafari et al. (2014) investigated the association of 11 morphological traits with 24 molecular markers (14 ISSR primers and 10 RAPD primers) in 15 cultivars of date palm. All regression models were significant for ISSR and RAPD markers and for all traits at level 1\%. Of 294 DNA markers (162 ISSR markers and 132 RAPD markers), 173 markers (89 ISSR markers and 84 RAPD markers) with at least one of 11 traits of fruit, stone and tree performance characteristics of both marker systems showed association. Basaki et al. (2011) reported that the 14 traits (excluding fruit shape, calyx type, Hull cracking sensitivity, and skin colour) showed significant association on a total of 14 of the 23 polymorphic SSR bands. The association markers explained from $2 \%$ to $29 \%$ of the variation of individual traits. 
In this study, multiple regression analysis was used to identify associations between ISSR markers with some agronomic traits in sand plantain ecotypes.

\section{MATERIALS AND METHODS}

\section{Plant material}

A total number of 17 sand plantain (Plantago psyllium) ecotypes, prepared at the National Centre for Genetic and Biological Resources of Iran, were chosen for this study on the basis of their yield potential and agronomical traits. The ecotype name, parentage and releasing centres are given in Table 1. The experiment was carried out in randomized block design with three replications during the season of 2016. Data was collected on morphological characteristics of sand plantain which include days to $50 \%$ flowering (DF), days to maturity (DM), plant height $(\mathrm{PH})$, number of spikes (NS), spike length (SL), number of grains per spike (NGS), spike weight (SW), 1000-grain weight (GW), and grain yield (GY).

\section{DNA extraction}

Fresh leaves were used for DNA extraction according to the modified protocol of Murray,
Thompson (1980). The quality of the extracted DNA was checked using agarose gel electrophoresis. In ISSR-PCR analysis, 12 primers were used. The polymerase chain reaction (PCR) was carried out in a total volume of $10 \mu \mathrm{l}$ per reaction containing $2 \mu \mathrm{l}$ of template DNA (5 ng/ $\mu \mathrm{l}), 1 \mu \mathrm{l} 10 \times$ PCR buffer, $1.2 \mu \mathrm{l}$ primer (30 ng $\mu^{-1}$ ), $0.6 \mu \mathrm{l}$ dNTPs, $0.48 \mu \mathrm{l}$ of $\mathrm{MgCl}_{2}$ $(50 \mathrm{mM}), 0.14 \mu \mathrm{l}$ Taq polymerase $(5 \mathrm{U} / \mu \mathrm{l})$, and $4.58 \mu \mathrm{L}$ of sterile nano-pure $\mathrm{H}_{2} \mathrm{O}$. The PCR reaction was performed in a thermal cycler (Applied Biosystems, Germany) at an initial denaturation temperature of $94^{\circ} \mathrm{C}$ for $5 \mathrm{~min}$, then 35 cycles of $94^{\circ} \mathrm{C}$ for $30 \mathrm{~s}, 55^{\circ} \mathrm{C}$ for $30 \mathrm{~s}$ (annealing of the majority of primers), $72^{\circ} \mathrm{C}$ for $2 \mathrm{~min}$, and the final extension at $72^{\circ} \mathrm{C}$ for $5 \mathrm{~min}$. The PCR products were separated in 3\% agarose gel electrophoresis.

\section{Scoring and data analysis}

DNA fragments were scored for the presence (1) or absence (0) of bands of various molecular weight sizes in the form of a binary matrix. The number of alleles per locus, Nei's gene diversity (h), polymorphism information content (PIC), marker index (MI), and Nei and Shannon's information index were calculated using Power Marker v. 3.25. Average values for all

Table 1. Geographical origins and code number of sand plantain (Plantago psyllium) ecotypes

\begin{tabular}{cccccc|c|c|c|cc}
\hline Code & State & Region & Height & $\begin{array}{c}\text { Code } \\
\text { in Gene } \\
\text { Bank }\end{array}$ & Code & State & Region & Height $\begin{array}{c}\text { Code } \\
\text { in Gene } \\
\text { Bank }\end{array}$ \\
\hline G1 & Tehran & Tehran & 1920 & 2390 & G10 & Bushehr & Ganaveh & 62 & 21252 \\
\hline G2 & Alborz & Karaj & 980 & 3968 & G11 & Lorestan & $\begin{array}{c}\text { Khor- } \\
\text { ramabad }\end{array}$ & 0 & 15803 \\
\hline G3 & Ilam & Dehloran & 150 & 3331 & G12 & Gilan & & -2 & 29719 \\
\hline G4 & Ardabil & Khalkhal & 1370 & 8401 & G13 & Gilan & Rudbar & 329 & 30910 \\
\hline G5 & Ardabil & $\begin{array}{c}\text { Meshgin- } \\
\text { shahr }\end{array}$ & 1339 & 30196 & G14 & Khuzestan & $\begin{array}{c}\text { Behba- } \\
\text { han }\end{array}$ & 942 & 32773 \\
\hline G6 & Ardabil & $\begin{array}{c}\text { Meshgin- } \\
\text { shahr }\end{array}$ & 1176 & 37951 & G15 & $\begin{array}{c}\text { Sistan and } \\
\text { Baluchestan }\end{array}$ & $\begin{array}{c}\text { Iran- } \\
\text { shahr }\end{array}$ & 400 & 22058 \\
\hline G7 & $\begin{array}{c}\text { Hor- } \\
\text { mozgan }\end{array}$ & $\begin{array}{c}\text { Bandar } \\
\text { Abbas }\end{array}$ & 1100 & 31536 & G16 & Mazandaran & Sari & -3 & 35571 \\
\hline G8 & Bushehr & Dashtestan & 430 & 21228 & G17 & $\begin{array}{c}\text { South Kho- } \\
\text { rasan }\end{array}$ & Qaen & 0 & 37496 \\
\hline G9 & Bushehr & Dashtestan & 700 & 21251 & \multicolumn{5}{c}{} \\
\hline
\end{tabular}


traits in this study were calculated for further analyses. The agronomic traits and molecular markers were considered as dependent variables and independent variables, respectively. In order to verify the linear relationship between independent and dependent variables, to predict the value of the dependent variable based on the independent variable, to remove the variables with negligible effect on the dependent variables, and to fit the best regression model, stepwise regression was used. Stepwise multiple-regression analysis (MRA) was performed to determine the association between the molecular data (independent variable) and phenotypic data (dependent variable). To identify the informative markers associated with six phenotypic and three biochemical fruit traits, MRA was conducted using the "linear regression analysis" method with the "stepwise" option of SPSS v. 20. The model of the analysis was

$Y=a+b 1 m 1+b 2 m 2+\ldots+b j m j+\ldots+b n m n+d+e$,

where $Y$ is the cultivar mean for a quantitative trait (dependent variable) and $m j$ is the AFLP marker (independent variable). The Student $t$-test was performed to test significance between mean trait estimates of genotypes where specific markers were present and absent. Markers show- ing significant regression values were considered as associated with the respective traits.

\section{RESULTS AND DISCUSSION}

Minimum, maximum, mean, standard deviation, and phenotypic coefficient of variation of traits are shown in Table 2. According to Table 2 , a considerable variation among ecotypes was observed for all evaluated traits. Most of the phenotypic variation among different traits related to 1000-grain weight and spike length traits in the amount of $29.34 \%$ and $20.05 \%$, respectively. We can thus say that there are genetic plant resources for use in breeding programmes to improve these traits. The lowest observed variations among the traits were for days to maturity (5.31\%) and spike weight (5.41\%). The phenotypic variation coefficient ranged from $5.31 \%$ to $29.34 \%$ for different traits.

In this study, 12 ISSR primers were used. ISSR markers produced a total of 129 bands, of which 91 bands were polymorphic and the average polymorphic loci per primer were evaluated 7.58 (Table 3). Twelve ISSR primers created 91 polymorphic bands, among them UBC813 with 11 bands, UBC811 with 10 bands. UBC814 and UBC817 primers with nine bands had the highest number of polymorphic bands

Table 2. Estimation of descriptive statistics of measured traits in the ecotypes of sand plantain

\begin{tabular}{c|c|c|c|c|c|c|c|cc}
\hline \multirow{2}{*}{$\begin{array}{c}\text { Descriptive } \\
\text { statistics }\end{array}$} & \multicolumn{7}{c}{ Traits $^{\mathrm{a}}$} \\
\cline { 2 - 10 } & DF & DM & PH & NS & SL & NGS & SW & GW & GY \\
\hline Mean & 66.29 & 94.49 & 19.81 & 4.28 & 2.05 & 84.01 & 76.78 & 1.41 & 237.54 \\
\hline $\begin{array}{c}\text { Standard error } \\
\text { of mean }\end{array}$ & 1.75 & 1.22 & 0.89 & 0.10 & 0.10 & 1.98 & 1.01 & 0.10 & 9.98 \\
\hline $\begin{array}{c}\text { Standard de- } \\
\text { viation }\end{array}$ & 7.22 & 5.02 & 3.66 & 0.41 & 0.41 & 8.18 & 4.15 & 0.41 & 41.14 \\
\hline Variance & 52.19 & 25.18 & 13.42 & 0.17 & 0.17 & 66.96 & 17.26 & 0.17 & 1692.46 \\
\hline Range & 26.33 & 18.33 & 11.01 & 1.37 & 1.42 & 24.87 & 16.41 & 1.37 & 129.67 \\
\hline Minimum & 55.00 & 89.00 & 14.67 & 3.79 & 1.53 & 70.51 & 68.37 & 0.92 & 177.24 \\
\hline Maximum & 81.33 & 107.33 & 25.68 & 5.16 & 2.95 & 95.38 & 84.78 & 2.29 & 306.91 \\
\hline $\begin{array}{c}\text { Coefficient of } \\
\text { variation (\%) }\end{array}$ & 10.90 & 5.31 & 18.49 & 9.53 & 20.05 & 9.74 & 5.41 & 29.34 & 17.32 \\
\hline
\end{tabular}

a The abbreviation of traits: $\mathrm{DF}=$ days to $50 \%$ flowering, $\mathrm{DM}=$ days to maturity, $\mathrm{PH}=$ plant height, $\mathrm{NS}=$ number of spikes, $\mathrm{SL}=$ spike length, NGS = number of grains per spike, $\mathrm{SW}=$ spike weight, $\mathrm{GW}=1000$-grain weight, GY = grain yield . 
Table 3. Number of polymorphic ISSR markers, effective multiplex ratio (EMR), marker index (MI), Nei, Shannon and polymorphic information content (PIC) values for each primer

\begin{tabular}{c|c|c|c|c|c|c|c|c|c}
\hline $\begin{array}{c}\text { ISSR } \\
\text { primers }\end{array}$ & $\begin{array}{c}\text { No. of } \\
\text { poly- } \\
\text { morphic } \\
\text { bands }\end{array}$ & $\begin{array}{c}\text { Total } \\
\text { bands }\end{array}$ & $\begin{array}{c}\text { Polymor- } \\
\text { phism, } \%\end{array}$ & $\begin{array}{c}\text { Poly- } \\
\text { morphic } \\
\text { information } \\
\text { index (PIC) }\end{array}$ & $\begin{array}{c}\text { Effective } \\
\text { multiplex } \\
\text { ratio } \\
\text { (EMR) }\end{array}$ & $\begin{array}{c}\text { Marker } \\
\text { index } \\
(\mathrm{MI})\end{array}$ & Shannon & $\begin{array}{c}\text { Number } \\
\text { of effec- } \\
\text { tive alleles } \\
\text { (Ne) }\end{array}$ \\
\hline UBC811 & 10 & 13 & 76.92 & 0.36 & 7.69 & 2.77 & 0.39 & 0.52 & 1.56 \\
\hline UBC812 & 8 & 11 & 72.73 & 0.30 & 5.82 & 1.75 & 0.3 & 0.48 & 1.43 \\
\hline UBC813 & 11 & 13 & 84.62 & 0.44 & 9.31 & 4.10 & 0.42 & 0.60 & 1.79 \\
\hline UBC814 & 9 & 14 & 64.29 & 0.27 & 5.79 & 1.56 & 0.18 & 0.46 & 1.37 \\
\hline UBC815 & 8 & 10 & 80 & 0.40 & 6.40 & 2.56 & 0.29 & 0.56 & 1.67 \\
\hline UBC816 & 7 & 11 & 63.64 & 0.34 & 4.45 & 1.51 & 0.33 & 0.51 & 1.52 \\
\hline UBC817 & 9 & 13 & 69.23 & 0.31 & 6.23 & 1.93 & 0.26 & 0.48 & 1.45 \\
\hline UBC823 & 8 & 11 & 72.73 & 0.37 & 5.82 & 2.15 & 0.3 & 0.53 & 1.59 \\
\hline UBC824 & 4 & 7 & 57.14 & 0.40 & 2.29 & 0.91 & 0.35 & 0.56 & 1.67 \\
\hline UBC825 & 5 & 8 & 62.50 & 0.39 & 3.13 & 1.22 & 0.36 & 0.55 & 1.64 \\
\hline UBC826 & 7 & 11 & 63.64 & 0.38 & 4.45 & 1.69 & 0.31 & 0.54 & 1.61 \\
\hline UBC876 & 5 & 7 & 71.43 & 0.41 & 3.57 & 1.46 & 0.31 & 0.56 & 1.69 \\
\hline Mean & 7.58 & 10.75 & 69.91 & 0.36 & 5.41 & 1.97 & 0.32 & 0.53 & 1.58 \\
\hline
\end{tabular}

and UBC824 with four bands had the lowest number of polymorphic bands. The mean of polymorphism percentage in the ecotypes was $69.91 \%$ for ISSR markers.

Solouki et al. (2008) evaluated the genetic diversity of German chamomile ecotypes using 29 RAPD primers. Among the 369 revealed bands, 314 bands were polymorphic. Pirkhezri et al. (2010) evaluated 25 German chamomile ecotypes using 18 RAPD primers, and obtained 220 bands, among them $93.1 \%$ were polymorphic. The average numbers of total and polymorphic bands obtained 12.2 and 11.4, respectively. Using four AFLP primer combinations, Heidary et al. (2009) studied the genetic diversity of barberry and observed 223 bands, of which 207 bands were polymorphic. Zhang et al. (2010) used AFLP markers for the investigation of the genetic variation among Glycyrrhiza uralensis ecotypes in northern China. In this study, 50 individuals from five ecotypes were used. In total, eight primer combinations produced 1025 bands, 57\% of which were polymorphic.

Polymorphic information content (PIC) is the equivalent of genetic diversity and shows the resolution of a marker by the number of polymorphic alleles and the frequency of these alleles in the studied population. Table 3 shows polymorphic information content calculated separately for each primer and the results. Polymorphic information content ranged from 0.27 to 0.44 and the calculated average of polymorphic information content was 0.36 for ISSR markers. The highest PIC for ISSR markers was for UBC813 (0.44) and UBC876 (0.41) indicating a high efficiency of these markers in differentiating the ecotypes used in this research. In order to determine the efficiency of markers in showing the polymorphism, MI and EMR were calculated. Effective multiplex ratio (EMR) is calculated as a total number of polymorphic loci per primer multiplied by the rate of polymorphic loci from their total number. Among ISSR markers, the highest amount EMR was for UBC813 (9.31) and the lowest was observed in UBC824 (2.29). The marker index (MI) is a statistical parameter used to estimate total utility of the marker system; the higher the MI, the better method is used. The marker index ranged from 0.91 to 4.10 . The average number of effective alleles was 1.58 in the population and ranged 
from 1.37 to 1.79 . UBC813 and UBC876 primers had the highest number of effective alleles among the all primers. Since the number of effective alleles is one of the important criteria in the selection of appropriate and useful primers, these primers could be used to investigate the genetic diversity of lemon balm ecotypes for future studies.

Pirkhezri et al. (2010) evaluated 25 German chamomile ecotypes using 18 primers, RAPD evaluated number of effective alleles, Nei's gene diversity, and the Shannon index for different provinces. The maximum and minimum amount for the number of effective alleles was observed in the Khuzestan province (1.657) and the Fars province (1.142), respectively. Nei's gene diversity and the Shannon index were higher in the ecotypes of the Khuzestan province $(\mathrm{Nei}=0.528$; Shannon $=0.364)$, and were lower than elsewhere in the ecotypes of the Fars province $(\mathrm{Nei}=0.23$; Shannon $=0.16$ ).

The results of stepwise regression analysis revealed a significant association between the traits and some of the studied loci (Table 4). In stepwise regression, traits and markers were considered as a dependent variable and independent variables, respectively. A total of 70 markers (alleles) were significantly correlated and associated with the studied traits; finally, 50 markers were effective in the phenotypic variation of traits because some markers were associated with more than one trait. Other markers had no significant effect on the model and therefore we can say that these correlated markers can be used to identify superior ecotypes in terms of studied traits. The markers identified varied from three markers for days to $50 \%$ flowering to 16 markers for the grain yield. These markers were negatively or positively correlated to traits. Other researchers used regression analysis to identify the relationship between markers and studied traits and used them in breeding programmes (Basaki et al., 2011; Ipek et al., 2015; Khadivi-Khub, 2014; Marsafari et al., 2014; Rakshit et al., 2010). Markers UBC814-3, UBC812-8, and UBC8265 were associated with days to $50 \%$ flowering and could justify $80.6 \%$ of the phenotypic variation. Also, markers UBC812-8, UBC825-4,
UBC813-10, UBC826-2, UBC812-7, UBC811-7, UBC813-8, UBC823-8, UBC811-6, UBC813-5, UBC823-1, UBC817-2, UBC813-1, UBC816-4, UBC876-4, and UBC814-7 showed a significant correlation with the grain yield and controlled 99.9\% of the phenotypic variation (Table 4).

In a multivariable regression model, each independent variable with a higher standard $\beta$ (in terms of value) is more important to the dependent variable. In this study, each marker (independent variable) that has a higher standard $\beta$ is more important for that trait (dependent variable). Marker UBC814-3 was the most important marker for days to $50 \%$ flowering and revealed a depressing effect. Also, UBC824-2 and UBC823-5 were important for the spike length and the number of grains per spike, respectively, and had an increasing effect (Table 4). According to the standard $\beta$ coefficients, some alleles lowered the effect and some alleles enhanced the effect of the studied traits (Table 4). Therefore, with regard to the breeding purpose of each trait (increasing some traits and reducing some traits is considered at breeding programmes), the standard $\beta$ coefficient of each marker can be used to improve that trait based on the breeding goal.

Identification of markers in the coding area of the traits can be important to those markers that are not located in this area. These markers can be identified using the regression method. Some of these markers were associated with more than one trait. According to a significant correlation between morphological traits, it can be seen that some of these traits had a very close linkage together or possibly were controlled by pleiotropic effects. The important advantages of association analysis are that in this method there is no need to prepare segregating population which requires more time, although it is better to use a multi-year phenotypic data. The efficiency of these methods has been shown for the identification and mapping of the controlling gene of Mendelian traits (Breseghello, Sorrells, 2006). It also uses informative markers associated with traits; in particular, markers of known chromosomal location can be an effective step taken in the initial selection of genotypes with high yield. 
Table 4. Informative markers associated with different morphological traits of the ecotypes of sand plantain (Plantago psyllium) detected by stepwise regression analysis

\begin{tabular}{|c|c|c|c|c|c|}
\hline Traits & $\begin{array}{c}\text { Number of in- } \\
\text { formative markers }\end{array}$ & Informative markers ${ }^{\star}$ & $\begin{array}{c}\mathrm{R}^{2} \text { adjusted } \\
(\%)\end{array}$ & $\begin{array}{l}\text { Important } \\
\text { marker }\end{array}$ & $\begin{array}{c}\text { Standard } \\
\beta\end{array}$ \\
\hline $\mathrm{DF}$ & 3 & $\begin{array}{c}\text { UBC814-3, UBC812-8, } \\
\text { UBC826-5 }\end{array}$ & 0.806 & UBC814-3 & -1.174 \\
\hline $\mathrm{PH}$ & 4 & $\begin{array}{l}\text { UBC812-6, UBC811-4, } \\
\text { UBC816-7, UBC826-5 }\end{array}$ & 0.845 & UBC812-6 & -0.733 \\
\hline NS & 13 & $\begin{array}{c}\text { UBC824-1, UBC813-10, } \\
\text { UBC825-5, UBC811-10, } \\
\text { UBC824-4, UBC823-4, } \\
\text { UBC817-5, UBC825-1, } \\
\text { UBC876-1, UBC813-7, } \\
\text { UBC815-7, UBC823-6, } \\
\text { UBC816-3 }\end{array}$ & 0.995 & UBC $813-10$ & -0.665 \\
\hline SL & 8 & $\begin{array}{l}\text { UBC824-2, UBC813-10, } \\
\text { UBC825-5, UBC811-10, } \\
\text { UBC824-4, UBC823-5, } \\
\text { UBC817-5, UBC825-1 }\end{array}$ & 0.981 & UBC824-2 & 0.721 \\
\hline NGS & 12 & $\begin{array}{l}\text { UBC811-3, UBC826-4, } \\
\text { UBC876-4, UBC823-5, } \\
\text { UBC817-3, UBC814-1, } \\
\text { UBC813-6, UBC823-7, } \\
\text { UBC812-6, UBC812-3, } \\
\text { UBC812-4, UBC812-1 }\end{array}$ & 0.993 & UBC823-5 & 0.629 \\
\hline SW & 8 & $\begin{array}{l}\text { UBC817-7, UBC824-3, } \\
\text { UBC876-3, UBC814-6, } \\
\text { UBC812-8, UBC811-4, } \\
\text { UBC815-5, UBC815-2 }\end{array}$ & 0.983 & UBC817-7 & -0.808 \\
\hline GW & 6 & $\begin{array}{c}\text { UBC824-1, UBC813-10, } \\
\text { UBC825-5, UBC811-10, } \\
\text { UBC824-4, UBC876-1 }\end{array}$ & 0.937 & UBC $813-10$ & -0.577 \\
\hline GY & 16 & $\begin{array}{l}\text { UBC812-8, UBC825-4, } \\
\text { UBC813-10, UBC826-2, } \\
\text { UBC812-7, UBC811-7, } \\
\text { UBC813-8, UBC823-8, } \\
\text { UBC811-6, UBC813-5, } \\
\text { UBC823-1, UBC817-2, } \\
\text { UBC813-1, UBC816-4, } \\
\text { UBC876-4, UBC814-7 }\end{array}$ & 0.999 & UBC $812-8$ & -1.023 \\
\hline
\end{tabular}

Therefore, by separating and cloning the informative marker region, we could identify the sequence of that region for each trait. Then the identified sequences was aligned in databases with existing sequences and, finally, can- didate genes were possibly identified for each trait. Also, a specific marker (SCAR primer based on identified sequences) can be designed for each trait and it can be used in marker-assisted selection breeding programme. 


\section{CONCLUSIONS}

Informative fragments could be successfully cloned and sequenced and used to design a specific marker (a SCAR primer based on identified sequences). It is to be hoped that some of these markers will be used for MAS in future lemon balm breeding programmes. In a breeding programme, crossing between more genetically distant individuals will increase the chance of transgressive segregation in their progeny. Therefore these markers could be used to choose parents for development of the mapping populations. The ISSR primer UBC81310 had the highest associated fragments with the traits. These primers have been found useful for the study of genetic diversity and association analyses in sand plantain.

\section{ACKNOWLEDGEMENTS}

We gratefully acknowledge the research funding provided for this project (No. 1142) by the Institute of Science and High Technology and Environmental Sciences, Graduate University of Advanced Technology, Kerman, Iran.

\section{CONFLICT OF INTEREST}

The authors declare that they have no conflicts of interest to disclose.

Received 18 February 2017 Accepted 12 June 2017

\section{References}

1. Atal C, Kapur B. Cultivation and utilization of medicinal plants. Jammu-Tawi, India: Regional Research Laboratory, Council of Scientific \& Industrial Research. 1982.

2. Basaki T, Choukan R, Khayam-Nekouei S, Mardi M, Majidi E, Faraji S, Zeinolabedini M. Association analysis for morphological traits in pomegranate (Punica geranatum L.) using microsatellite markers. Middle-East J Sci. 2011; 9(3): 410-7.
3. Breseghello F, Sorrells ME. Association analysis as a strategy for improvement of quantitative traits in plants. Crop Science. 2006; 46(3): 1323-30.

4. Davazdah Emami S, Majnoon Hosseini N. Cultivation and production of medicinal plants and spices. Tehran, Iran: Tehran University Press. 2008. Persian.

5. Deokar G, Kshirsagar S, Deore PA, Kakulte H. Pharmaceutical benefits of Plantago ovate (Isabgol seed): a review. Pharmaceutical and Biological Evaluations. 2016; 3(1): 32-41.

6. Gebhardt C, Ballvora A, Walkemeier B, Oberhagemann $P$, Schüler K. Assessing genetic potential in germplasm collections of crop plants by marker-trait association: a case study for potatoes with quantitative variation of resistance to late blight and maturity type. Molecular Breeding. 2004; 13(1): 93-102.

7. Ghahreman A. Colored flora of Iran. Tehran, Iran: Research Institute of Forests and Rangelands 1975. Persian.

8. Gomez KA, Gomez AA. Statistical procedures for agricultural research, 2nd edition. New York: John Wiley \& Sons. 1984.

9. Heidary S, Marashi H, Farsi M, Mirshamsi Kakhki A. Assessment of genetic structure and variation of native Berberis populations of Khorasan provinces (Iran) using AFLP markers versus morphological markers. Iranian Journal of Biotechnology. 2009; 7(2): 101-7.

10. Henshall J, Goddard M. QTL detection using multiple regression on average transmission probabilities. Proceeding of Association for the Advancement of Animal Breeding and Genetics. 1999; 13: 219-22.

11. Ipek M, Seker M, Ipek A, Gul M. Identification of molecular markers associated with fruit traits in olive and assessment of olive core collection with AFLP markers and fruit traits. Gen Mol Res. 2015; 14(1): 2762-74.

12. Kang DH, Jung EY, Chang UJ, Bae S-H, Suh HJ. Psyllium husk combined with hydroxycitrate reduces body weight gain and body 
fat in diet-induced obese rats. Nutr Res. 2007; 27(6): 349-55.

13. Khadivi-Khub A. Regression association analysis of fruit traits with molecular markers in cherries. Plant Syst Evol. 2014; 300(5): 1163-73.

14. Marsafari M, Mehrabi AA, Tahmasebi Z. The identification of RAPD and ISSR informative markers with some quality traits of fruit in some of Iranian date palm. International Journal of Plant, Animal and Environmental Sciences. 2014; 4(2): 714-22.

15. Murray M, Thompson WF. Rapid isolation of high molecular weight plant DNA. Nucleic Acids Res. 1980; 8(19): 4321-6.

16. Pirkhezri M, Hassani M, Hadian J. Genetic diversity in different populations of Matricaria chamomilla L. growing in Southwest of Iran, based on morphological and RAPD markers. Research Journal of Medicinal Plants. 2010; 4(1): 1-13.

17. Rahn K. A phylogenetic study of the Plantaginaceae. Botanical Journal of the Linnean Society. 1996; 120(2): 145-98.

18. Rakshit A, Rakshit S, Singh J, Chopra S, Balyan H, Gupta P, Bhat SR. Association of AFLP and SSR markers with agronomic and fibre quality traits in Gossypium hirsutum L. Journal of Genetics. 2010; 89(2): 155-62.

19. Rosatti TJ. The Plantaginaceae in the southeastern United States. Journal of the Arnold Arboretum. 1984; 65(4): 533-62.

20. Schulman AH. Molecular markers to assess genetic diversity. Euphytica. 2007; 158(3): 313-21.

21. Solouki M, Mehdikhani H, Zeinali H, Emamjomeh A. Study of genetic diversity in Chamomile (Matricaria chamomilla) based on morphological traits and molecular markers. Scientia Horticulturae. 2008; 117(3): 281-7.

22. Zhang J-T, Xu B, Li M. Genetic diversity of populations of an endangered medicinal plant species (Glycyrrhiza uralensis) in different environments of North China. J Med Plants Res. 2010; 4(9): 830-6.
23. Zietkiewicz E, Rafalski A, Labuda D. Genome fingerprinting by simple sequence repeat (SSR)-anchored polymerase chain reaction amplification. Genomics. 1994; 20(2): 176-83.

Mehdi Rahimi, Hamid Hatami Maleki, Mojtaba

Mortezavi

AGRONOMINIŲ SAVYBIŲ IR INFORMATYVIŲ ŽYMENŲ IDENTIFIKAVIMAS SKIRTINGUOSE SMILTYNINIO GYSLOČIO (PLANTAGO PSYLLIUM) EKOTIPUOSE

\section{Santrauka}

Norint ịvertinti smiltyninio gysločio (Plantago psyllium) agronominių savybių ir molekulinių žymenų ryši buvo tiriama 17 ekotipų Irane. Daugybine regresijos analize buvo patikrinta 12 ISSR žymenų ir nustatytas ryšys tarp žymens ir agronominių savybių. Dvylika žymenų buvo polimorfiški, iš viso buvo pagausinti 129 fragmentai (lokusai). Nustatyta 70 ISSR fragmentų, susijusių su morfologinèmis savybèmis. Kai kurie ISSR žymenys buvo susiję su daugiau nei viena savybe daugybinèje regresijos analizėje ir tą galejjo lemti kiekybinio požymio lokuso pleiotropinis poveikis skirtingiems bruožams arba skirtingiems genų ryšiams.

Raktažodžiai: ISSR žymenys, žymens ir savybès ryšys, daugybinè regresija, polimorfizmas 